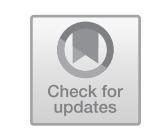

\title{
Just Say No to the Majors: Independent Hip-Hop Culture
}

\begin{abstract}
This chapter aims to uncover how independent hip-hop in the post-golden era challenges or reproduces cultural ideologies within US mainstream hip-hop culture and US culture more generally. Based on a content analysis of artists' lyrics, the author identifies three recurrent themes found in albums by twenty-five indie hip-hop artists. First, these acts resist the majors through mainstream artists, large radio stations, and major record labels. Second, they reject the corporatization and commodification by major record labels and mainstream culture in favor of independently owned companies. Third, they advocate for an indie culture based on alternative cultural ideals. They instead socially construct and advocate for a brand of authenticity rooted in hip-hop's origins.
\end{abstract}

Keywords Independent hip-hop - Authenticity - Corporatization and commodification - Mainstream hip-hop - Major record labels • Independent record labels

Immortal Technique's song, entitled “One Remix" (2003a), emphasizes the sentiments of many independent artists who believe that hip-hop needs to continue to be free from economic and cultural control by large corporations who dominate mainstream culture. As Rose (2008) states, three record labels nicknamed the "majors" (Universal Music Group, Sony Music Entertainment, and Warner Music Group) distribute more than $85 \%$ of the music globally in the industry. Conversely, independent

(C) The Author(s) 2019

C. Vito, The Values of Independent Hip-Hop in the Post-Golden Era, https://doi.org/10.1007/978-3-030-02481-9_2 
hip-hop focuses on music created by established indie labels and produced outside the confines of the three major music labels (Vito 2015). While these terms are not binary or dichotomous as independent and major label artists often mediate both realms, they provide an important framework for indie musicians to make economic and cultural grievances toward major corporations and mainstream culture.

With this demarcation by artists who have willingly chosen to remain independent, they make similar claims regarding class relations within the music industry that also reflect broader class relations in the USA. While these claims remain heterogeneous and fall along a broad spectrum, similar underlying themes can be found within their lyrical content. Thus, this chapter discusses three recurrent themes found in albums by twenty-five independent hip-hop artists in the post-golden era from 2000 to 2013. First, these acts resist the majors in three ways: (1) mainstream artists, (2) large radio stations, and (3) major record labels. Second, they reject the corporatization and commodification by large record companies and mainstream culture in favor of independently owned companies. Third, they socially construct and advocate for independent hip-hop based on alternative cultural ideals.

\section{Resistance TO THE “Majors"}

Independents often criticize major record label culture, citing the commodification, exploitation, and corporatization of hip-hop as major problems. In particular, the artists studied express resistance: (1) to mainstream artists who "sell out," (2) to large radio stations, and (3) to major record label control of music.

\section{Resistance to Mainstream Artists Who "Sell Out"}

The fall of the golden era in the 1990s was spurred on by the extraction of artists into the mainstream by major record labels looking to capitalize on hip-hop's emergence. Johnson (2008) believes that during this time, there was a significant decrease in lyrical mastery, innovation in beat production, and diversity in style and content. This shift was caused by the desire of large corporations to secure their investments by standardizing the music creation process and creating a market aimed at homogenization (Myer and Kleck 2007). 
Indies express grievances toward major label musicians who have been complicit in this process of homogenization in hip-hop culture. For example, Subterraneous' Binary Star rap in "Masters of the Universe" (2000a): "subtle, anonymous, rap hippopotamus, milk homogeneous." Their album, which was produced with a very limited budget and a small market, garnered rave reviews for its varied beats and rhymes as an alternative to many mainstream acts during the time (Mills 2000). Similarly, Hieroglyphics Imperium's Hieroglyphics Crew writes in "Let it Roll" (2003a): "an exception to the mediocrity, monotony and hypocrisy, That hip hop is weak." Both groups write about the music industry catering to the needs of the masses through standardization and thus minimizing the importance of the creativity, heterogeneity, and innovation exhibited during the golden era.

In addition, they argue that major label artists have utilized two tropes of hip-hop culture to make music that is repetitive in theme (Watkins 2005). Indies criticize acts from major labels that utilize the "gangster rap" phenomena to objectify street culture as a means to be successful. Also, they reject hip-hop that focuses solely on making money and "getting rich."

During the first period of the post-golden era, the dominant model used by large corporations was gangster rap, which emphasized nihilism, machismo, and violence (Rose 2008; Taylor and Taylor 2007; Wells-Wilbon et al. 2010). While these tropes of gangster rap resembled street culture, corporations have ossified these tropes into albums to be created and consumed by the masses. Independent performers add that many rappers today often talk about being hardcore and gangster because that appeals to whites in the mainstream. Concurrently, they claim that these acts are not "hard" but rather create a façade to sell records. As Binary Star raps in "Honest Expression" (2000b), "I ain't hardcore...most of y'all gangsta rappers ain't hardcore neither." "Honest Expression" (2000b) picks up on the same themes, asking "what makes you think you're hardcore, cause you was raised in the projects?" For Binary Star mainstream acts and major corporations corroborate to create stereotypical images embedded within urban culture simply to make a profit.

Much of hip-hop is also marred by the trope of the "bling bling" era. Many acts uphold the stereotype that urban culture is dominated by the consumption of material goods such as money, jewelry, and 
cars. This materialism permeates into the lyrical content of the majors. Binary Star asks in "Binary Shuffle" (2000c) "do you want to hear about the money we got? (oh no), talk about the people we shot? (oh no), bragg on the clothes we wear? (oh no)." Their lyrics object to music focused on money, gang violence, and material consumption as the basis for lyrical content. KRS-ONE adds that this trope of materialism gives many musicians entering the game the wrong idea about the industry in "Nothing New" (2007). KRS-ONE raps that the industry has changed since the golden era, facing increased corporatization and homogenization into a bling-bling genre. New acts coming into the industry believe that it always opens gateways to wealth and fame, but are mistaken as hip-hop is still dominated by large corporations who control the culture and its profits. In essence, many musicians are led to believe and even reinforce the cultural ideologies of materialism in their lyrics, which in turn is reproduced by listeners and broader mainstream culture.

Further, these complaints have led indie artists to argue that many acts signed to the majors have sold out by creating a formulaic package with similar messages to attract large audiences to their music, sacrificing the art of hip-hop culture. The increase of homogenization, the commodification of gangster rap, and the ideology of materialism have led them to conclude that hip-hop has been jeopardized by sell outs. Bay Area rap duo Blackalicious reiterates these sentiments in "Purest Love" (2002): “how can I rap, if I ain't thugged out pimpin', flossin' my ice, packin' a gat," stating that they do not want to "sell (their) soul and front inside of mainstream's eyes" (Fig. 2.1).

Many musicians argue that rappers have sold out in two ways: (1) they merely act as puppets following orders from major labels and (2) becoming successful by creating a worn down and noncreative product that large companies want. As puppets, mainstream acts have been accused by the hip-hop community as being sell outs who have given in to the ideologies of the corporations to get their cut of the profits in the industry. For instance, in Hieroglyphics" "Prelude" (2003b), they claim that they have stayed true to hip-hop, while many rappers are just "parrots" who do what they are told in order to get rich. Sound of Color's duo of Blu and Exile rap in "Simply Amazin" (2007a) "fuck you sold-soul rappers, after diamonds and pearls." Binary Star reiterates these sentiments 


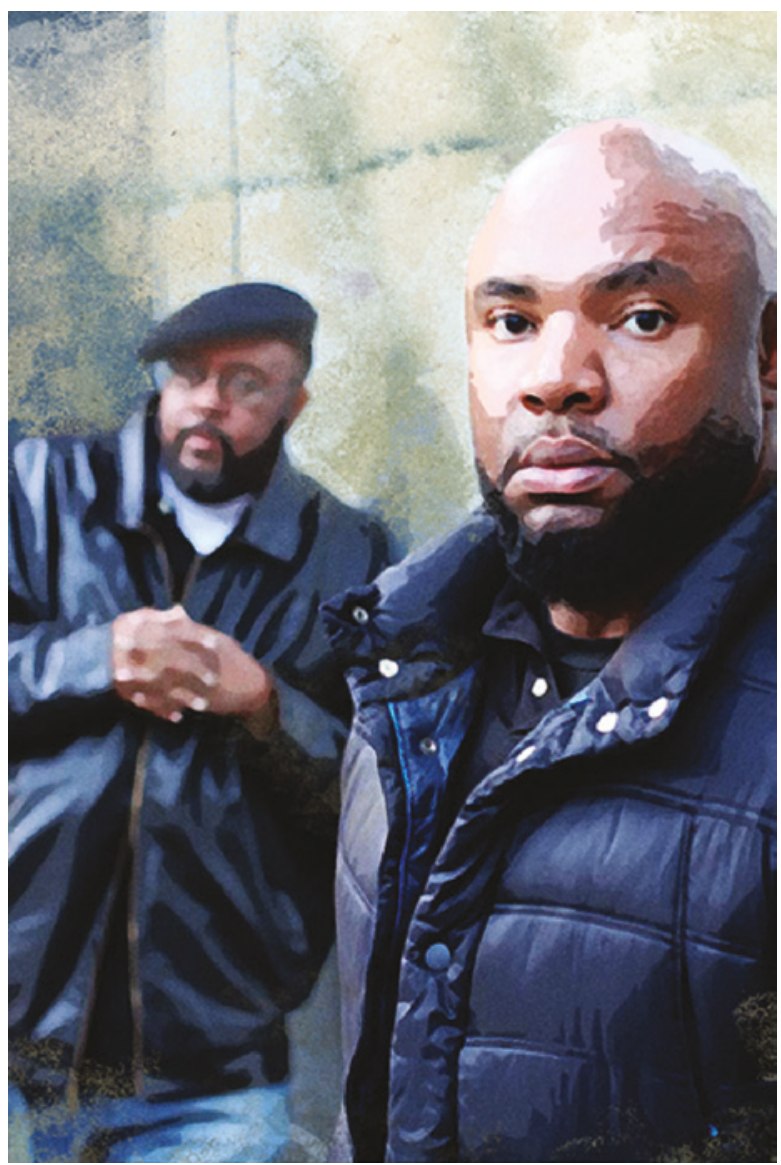

Fig. 2.1 Blackalicious (Gift of Gab on left and Chief Xcel on right) (Credit Blackalicious.com)

in "Indy 500" (2000d): "they pay your dumb ass...to get rich." In these songs, they denigrate rappers who sold out for the money and who do not care about the music and the message. Instead, these rappers homogenize the sound and play on tropes of minority communities at the request of the major companies and at the expense of the culture. 
Independent musicians also make the claim that many artists create a worn down product that is noncritical and noncreative. Binary Star writes in "Honest Expression" (2000b) that "every gold record don't glitter that's for damn sure." Similarly, Viper Records' Immortal Technique raps on "Industrial Revolution" (2003b) "if you go platinum...it just means that a million people are stupid as fuck." Both acts make the argument that financial and commercial success does not translate into quality music production. Instead, it shows that they can create a product that has traditionally been successful and can capitalize on the tastes of the broader market. Ultimately, indies claim that mainstream hip-hop culture is homogenized, reproducing and recreating gangster rap and bling-bling tropes to achieve commercial success despite selling out on hip-hop.

\section{Resistance to Major Radio Stations}

After hip-hop's meteoric rise in America, large companies such as Cumulus Media and iHeartMedia (formerly Clear Channel) have used their control of major radio stations to flood the market with musicians they support. While the practice of payola, or paying radio stations for airplay, is illegal in the USA, many corporations have found loopholes through independent promoters to maintain dominance of the airwaves. For example, it may cost up to $\$ 1000$ to play one song per station in the USA (Ball 2009). This has led to the cultural practice of favoring the majors rather than the independents. Many indie acts have thus rejected the cultural practices of large radio stations and mainstream media outlets. They argue that radio stations actively cooperate with the large corporations to create, promote, and maintain homogeneity in mass media simply to get paid. Concurrently, this also means that indies have a hard time getting "spins" from large radio outlets and mainstream media sources because they lack the cultural capital, as well as economic capital (see Chapter 3), to get "love" from the big outlets. In turn, this creates feelings of marginalization as they are forced to live in the underground.

Independent hip-hop remains at the margins of the major radio stations and thus has remained a niche market predominantly spurred on by local radio stations. Yet the cornering of the radio market by iHeartMedia (formerly Clear Channel) has worsened the marginalization 
independent musicians experience as their opportunities have diminished. Binary Star raps in "Honest Expression" (2000b) that radio stations play "nonsense." It's A Wonderful World Music Group's Rapsody raps in "Kind of Love" (2012a) that this change has diminished and tarnished hip-hop culture: "kind of love uncommon nowadays, Used to Love Her on my radio waves." In the verse, Rapsody references Common's song "Used to Love Her," reiterating his sentiments that hip-hop has changed in the face of corporatization and commodification by mainstream radio.

Indies have also had a hard time getting love from other media outlets. Rapsody writes in "The Cards" (2012b) about her struggles to get major airplay on MTV and BET. She claims these are not an anomaly, but rather indicative of the market as local DJs and musicians have a hard time getting brand recognition without the social, cultural, and economic capital of the large labels. Further, Rapsody argues that there is no space to make grievances about major radio's cultural practices as the corporate executives suppress their complaints. In "Believe Me" (2012c), she raps "complaining bout radio, my nigga, got no room, cause niggas wit opinions don't support you on iTunes." Indies understand that major radio stations and media outlets align themselves with the interests of the majors, which makes it difficult for them to obtain a larger share of the radio waves in the hip-hop industry.

\section{Rejection of Interactions with Record Labels}

Rose (2008) contends that the corporatization of hip-hop has had deleterious effects for hip-hop culture and its community. For example, corporatization has created an overrepresentation of white, upper-class males in positions of power in the music industry who control the direction of the culture (Myer and Kleck 2007). As a result, mainstream acts are forced to adopt the ideologies and practices of large corporations in order to be successful. Independents have alternatively developed negative views of the majors as they have been culturally marginalized in the industry.

In particular, they make three main grievances toward major corporations. First, indies voice their negative experiences with the majors when negotiating their behavior, ideas, and creative direction in their music. Second, they argue that the large companies are willing to pull artists and 
their culture from the underground to commodify them into a product when they are failing. Finally, indie artists who consider being part of a large label face the problem Immortal Technique (2003d) calls being "stuck on a shelf," or being "shelved." He argues that many artists have their music stuck in limbo and sometimes never even being released. In essence, they believe that indies are treated poorly if they are part of the underground circuit until the majors pull them from the underground when necessary. Once they are pulled from the underground, the culture of objectification has led many to be unsuccessful and treated as expendable workers for the industry.

Indies express their hesitation and distrust of the major record labels. As Sound of Color's Blu and Exile write in "Soul Amazing" (2007b), "I give a fuck about a pro hire." Blu and Exile describe their distrust of pro hires, or professional hiring companies focused on marketing and distribution, and the importance of remaining with smaller labels. Much of their distrust stems from negative experiences with the majors when negotiating their behavior, ideas, and creative direction in their music.

Lex Records' MF Doom raps on "Gazillion Ear" (2009): "once sold an inbred skinhead a nigga joke." In the verse, he is referring to the release of the album Black Bastards by KMD, a rap group that included MF DOOM. The album was canceled by Elektra Records, a subsidiary label owned by Warner Music Group, because of its controversial cover depicting a black Sambo figure being lynched. They cited the cover as depicting racist stereotypes, despite KMD's history of racially conscious lyrics and satirical artwork. KMD was subsequently released from Elektra despite KMD member DJ Subroc being killed in a car accident shortly before the album's completion (Ducker 2014). After retreating from hip-hop for years, MF DOOM resurfaced onto the indie scene. In his lyrics, he states his desire to stay away from labels such as Elektra Records as he feels that they limit his ability to speak on race relations and that many performers face detrimental consequences for criticizing or bringing attention to racism and racial problems.

Strange Records' Tech N9ne writes of his displeasure with the major record labels in "Like Yeah" (2008a): "the industry's still punks, that's why they real slump...all our records we will dump." On the track, he raps of his distrust of the industry, emphasizing the need to thrive on his own label. This stems from his negative experiences with Warner Bros in the 1990s. Tech N9ne fell out of favor with Quincy Jones and the label 
because he did not fit their artistic mold (Greenburg 2013a). He was eventually released from his deal as the company cites that Tech N9ne's hardcore rap "just wasn't working." He later formed Strange Records with partner Jimmy Gunn and openly stated that he would never go mainstream (Tucker 2015). The experiences of MF DOOM and Tech N9ne resemble the experiences of many indies that tried to make it in the game and were marginalized by the labels because they did not fit their cultural schema.

Indies have also made the grievance that companies pull from the underground and independent scene when they need a new source of innovation. Once indie musicians and their styles are commodified by mainstream labels, they exploit this innovation for their own profit without consideration for the artist. As Rhymesayer's Atmosphere points out in "God Loves Ugly" (2002a), "everybody gathers around...so they can steal each others' sound." They have additionally claimed that many acts are viewed as fads by companies, which leads them to often be stuck trying to survive in the larger market without much support. In "One of a Kind" (2002a), Atmosphere continues to spit: "switch up my styles... but see which kids next year sound the same as me." Indies such as Atmosphere believe that corporations pull acts from the underground as a form of cheap labor to produce fads and trends with no concern for the negative short-term and long-term consequences.

Further, independents have complained about the phenomenon of being "shelved," or having their music be stuck in limbo and sometimes never even being released (Platon 2017). A number of situations can contribute to an act's lack of success in the industry. For example, musicians are often bound by contracts and can be shelved if they encounter conflicts with upper management (Michaels 2010). A young MF Doom, as part of rap group KMD, had their album Black Bastards shelved by Elektra in 1993 due to disputes over album cover art featuring a Sambo figure being lynched (Steiner 2014). Their album was not released until 2001 under Ready Rock Records. In addition, the preponderance of signings by major labels is astoundingly high considering the small number of artists they actually promote each year. Many acts have thus complained that musicians signed in-house to these labels must fight with one another for scant access to resources and the opportunity to be successful in the market (Zafar 2013). Macklemore LLC's Macklemore and Ryan Lewis write in "Jimmy Iovine" (2012a): "CDs boxed in cardboard, 
artists that flopped, that got dropped and never got to be sophomores." The practice of shelving has led many to rot away in the music game without ever having an opportunity to release their songs to the public. During their music careers, many get stuck in different phases such as recording, distribution, and even touring. Underlying the majors' actions are the justification that signing many musicians keeps competition high, and thus acts are willing to take less in profits and resources. Many companies have also kept artists on the shelves at record stores and big-box chains to fill the shelves with acts that they know will flop or not sell (Lindvall 2010; Zafar 2013). This is done to keep shelf space full and divert attention to albums that the record company is pushing. Even with the decline of physical records, major record labels are still known to shelve musicians by signing them, recording their music, and then refusing to release it digitally. This creative marketing tactic is used at the expense of many musicians whom never get a full opportunity to let their work be put on the market. Many complain that major record labels keep acts metaphorically and physically shelved as objects that are exploited in the industry.

Ultimately, they are weary of the culture of objectification and expendability in the mainstream. Rap duo Binary Star writes of the lack of concern for artists in "Indy 500" (2000d). They spit: "and if that shit don't hit, the next day you're gone." Their lyrics reveal the nature of the "beast" in the industry. Musicians are generally seen by large corporations as employees who produce a commodity. When they are unable to make the company profitable, they are seen as expendable and replaceable regardless of its effect on their livelihood, family, friends, and community. The problem of commodification has ultimately left independents weary of major record labels and their cultural practices in the music industry.

\section{Fighting Back Against the Majors}

Hip-hop has consistently faced the problematic pull between commercial vitality and a meaningful source of youth empowerment and social change (Watkins 2005). As a result of commercialization in the postgolden era, independent labels began to grow again as a push-back from artists and listeners who were concerned with hip-hop's shift toward capitalistic, patriarchal, Eurocentric, heteronormative, and noncritical 
culture (Dyson 2010; Ogbar 2007; Perry 2004; Rose 2008; Watkins 2005). Thus, indies have made the claim, albeit with heterogeneous themes, that they need to create and maintain a niche market predicated upon independent labels and culture (Drake 2015). Their argument, based on their lyrics, appear in two differing ways: (1) the need to create independent companies to maintain a niche culture in the music industry and (2) the need to question, reject, and rebel against major record labels and mainstream culture. Both make the assertion that independent companies need to remain a subculture that allows for more cultural freedom and creative expression.

\section{Creation of Independent Labels and Culture}

Ball (2009) emphasizes the importance of material conditions in music creation and production. In order to understand hip-hop one must examine the creation of independent hip-hop companies and culture. Previous research (Berger and Peterson 1975) states that competition, diversity, and resistance (Hesmondhalgh 1999) in the music industry historically occurs following periods of homogeneity, which mirrors the rise of independent labels in the post-golden era. For instance, indies remove themselves from the corporate infrastructure through DIY (Do It Yourself) ethics (Moore 2007), or self-production (Harkness 2012), which allows for more cultural and economic freedom (Maher 2005). They can also look for alternative means of press through independent radio outlets, Web sites, and social networks with the rapid rise of music technology (Ball 2009; Jones 2002). This is epitomized in the creation and success of hip-hop record labels operating outside of major record label's mainstream culture.

Independents believe that the industry needs to be predicated upon the creation of companies that are predominantly interested and invested in the musicians' best interests. They contend that acts can be successful in the music industry while simultaneously being free from corporate control and creating their own culture. For example, rap collective Hieroglyphics writes in "Powers That Be" (2003c) "and the industry could never jail us, all my niggas free to be ourselves and our records still sell." Their album, Full Circle, was released in 2003 to positive reviews from critics and successful record sales in the independent album category (Bush 2003). They achieved financial 
and commercial success despite being a collective of artists who were deemed not commercial enough for many major labels. Viper Records' Immortal Technique echoes those sentiments by writing on "The Message and the Money" (2003c): “you don't own me, and none of you niggas ever will." In an interview with Immortal Technique, he reiterates these statements by claiming that his music is $100 \%$ independent, which he characterizes as owning your own masters, publishing, and creative control (The NE Hip-Hop 2013). Both acts emphasize the value of being free from major records' label control through the creation of independent companies and remaining outside of the mainstream market. As a result, they experience less direct oversight by corporate producers and can create their own niche culture and brand of music.

\section{Rejection and Rebellion Against the Majors}

The dialectical nature of hip-hop also allows for artists and listeners to create and interpret meaning from music, which can simultaneously promote dominant ideologies and resist them (Watkins 2005). These modes of resistance can be present in ciphers (freestyles among rappers), live performances, recorded music, and social media (Newman 2005). They often operate as hidden transcripts, or encrypted messages understood within the hip-hop community, that act as a form of resistance and a means of opening dialogue among artists and listeners (Ferris 2007; Hess 2005; Potter 1995). Indies in particular produce hidden transcripts regarding their experiences as marginalized actors dissatisfied with their position in mainstream culture and society. As KRS-ONE points out, hip-hop is in a unique position to critique society, which includes topics of racism, police brutality, incarceration, and poverty (Akom 2009; Au 2005; Dimitriadis 2009; Hill 2009). Their music also acts as a means to resist and rebel against the corporatization and commodification of hiphop's culture by major record labels. In certain instances, these themes of resistance and rebellion create a collective identity predicated upon a shared recognition as working-class people of color (Leard and Lashua 2006). Within my sample, collective grievances appear in lyrics emphasizing their ability to speak freely regarding political and cultural ideologies and lyrics calling for resistance and rebellion against the majors and mainstream culture. 
Independent artists have rapped about their ability to speak freely and make music aligned with their political and cultural views. Viper Records' Immortal Technique writes in "Freedom of Speech" (2003d): "independent in every single sense of the word, I say what I want." $\mathrm{He}$ raps that being indie affords him the ability to speak his mind and not be controlled by any executives who may censor his political beliefs. Other acts have similarly shared these sentiments. Sound of Color's Blu and Exile rap in "The Narrow Path" (2007c): “just dig it, or don't fuck with it, cause you can't fuck with it." Om Records' People Under the Stairs also spit in "Acid Raindrops" (2002a): "underground ground heads will fiend this musical genius." They both make the case that underground and independent hip-hop is a market in which they can engage in a wide array of sounds, styles, and lyrics. Hieroglyphics reiterates these sentiments in "Prelude" (2003b) by claiming to be "ahead of the charts." Hieroglyphics reinforces the assertion that being free from record label control allows many performers to be creatively free and offers a chance to be successful without compromising their political and economic beliefs.

Indies are also in a unique position to make the grievance that they need to create social change against the cultural practices of marginalization and objectification by the majors. Immortal Technique elaborates on his song "The Message and the Money" (2003c): "I would like to send a message to all the underground MC's...the time has come to realize you networked in a market, and stop being a fucking commodity." $\mathrm{He}$ argues that this rebellion must be spurred on by the notion that indie artists are seen as a commodity rather than musicians creating music both for themselves and for fans. As such, he writes that "hardcore reality hip-hop" is shunned by companies because it is not viewed as a profitable market by record executives and managers. Other independents have reinforced Immortal Technique's sentiments. As Subterraneous' Binary Star writes on "Conquistadors" (2000e): "the system we rebel, the mainstream as well." Hieroglyphics Imperium's Hieroglyphics also rap in "Powers That Be" (2003c): "fuck popular opinion...but we did it all for independence." Furthermore, the sources of these grievances can be heterogeneous from person to person. Tech N9ne and Immortal Technique demonstrate in their lyrical content, with the former focusing on darker religious lyrics and the latter focusing on economic and political issues, that heterogeneity in their lyrics does not inhibit their 


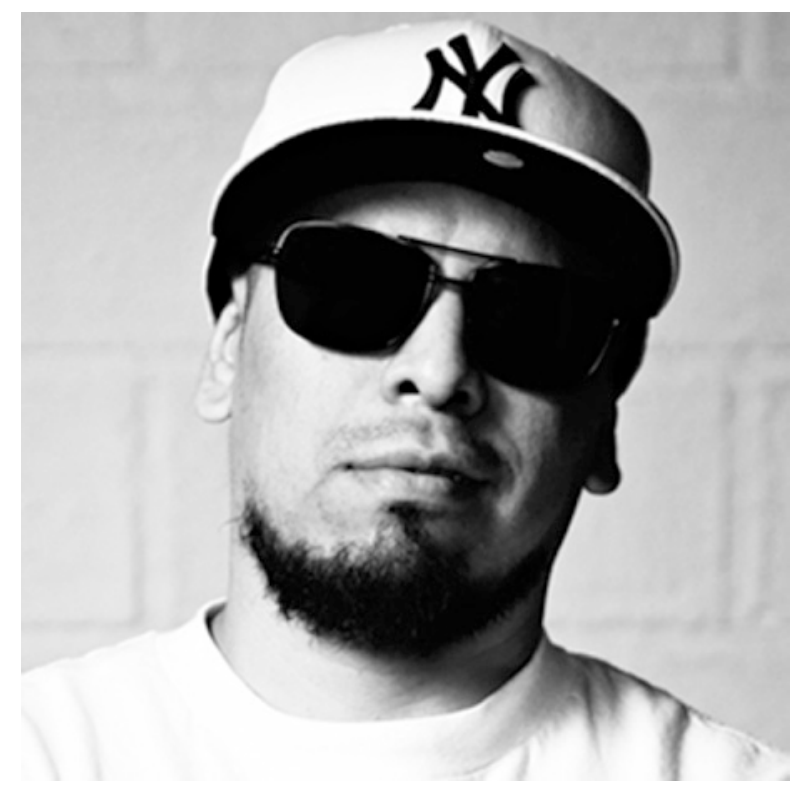

Fig. 2.2 Immortal Technique (Credit Twitter @ImmortalTech)

collective grievance of the music industry. As they show in an interview together, they both advocate for a rebellion against major labels upon the premise that the majors objectify them and deny their autonomy and creative control (Hard Knock TV 2013). Ultimately, indies have expressed the need for rebellion and change within the music industry, which begins with creating an independent market predicated upon freedom from major corporations and the production of alternative cultural ideals (Fig. 2.2).

\section{Independent Hip-Hop as an Alternative Culture}

Independent artists have advocated for the rejection of major record labels and the creation of indie companies. In concordance with the formation of indie companies, some artists of this genre argue for an alternative culture predicated on the love of hip-hop music, or creating music regardless if the musician becomes rich and successful. Others in the 
genre utilize claims that "real" or "authentic" hip-hop requires acknowledging and honoring its origins.

\section{For the "Love" of the Music Regardless of Money}

The bifurcation between the independent and major circuit is not new, as indie rock has exhibited the same "social differentiation" (Hibbett 2005) from mainstream rock as a form of high art. Hibbett (2005) describes the antagonism between indie and mainstream rock as highly responsive to one another and interdependent. Scholars (Maher 2005, 2007; Rose 2008) make similar arguments regarding independent hip-hop as a dialectical force that legitimizes mainstream hip-hop by pulling some of its acts from the indie scene but distancing itself from the mainstream by pulling away from overt commercialization. Harrison (2006) reiterates this point by claiming that indie artists can embrace the progressive politics of subcultural inclusion in the industry. This can include lyrics that critique the domination by major corporations in popular culture and society, as well as provide an alternative indie culture predicated on alternative ideals.

Independent label Rhymesayers, which is based in Minnesota and co-created by Atmosphere (consisting of Rapper Slug and DJ/Producer Ant), has acts that have created an identifiable brand of indie culture claiming that their music is predicated upon their "love of the music." For example, Atmosphere raps about their love for hip-hop on "Give Me" (2002b), elucidating the importance of hip-hop in their own lives. They also write of the love they have for their fans, which is embodied in the music that they create and the personal relationships they form with them (Ostrow 2010).

Fellow Rhymesayers signee Aesop Rock advocates that he has a passion for making music and is dedicated to his craft. Aesop Rock's journey was unconventional as he initially funded his own debut album in 1997 entitled Music for Earthworms before being signed to independent label Mush in 1999. He was later signed by indie label Definitive Jux and released Labor Days in 2001. After a hiatus on Definitive Jux, Aesop Rock signed with Rhymesayers. In Aesop Rock's "Labor" (2001a), he writes: "I work past the surface, and I'll work until this here little flat line closes the curtains." On the track, Aesop describes that hip-hop is his life 
and he loves it. He views hip-hop as a lifelong commitment to which he develops his craft. More importantly, his love for the music transcends his material success as he works to survive and will perform, both literally and figuratively, until the curtain closes.

Rhymesayer label mate Brother Ali reinforces his dedication and love for the quality of music he creates. Brother Ali, a white male rapper who was born with albinism, has been with Rhymesayers since his first release entitled Rite of Passage in 2000. On the track entitled "The Preacher" (2009a) off of the album $U s$, he spits: “me, I'm an artist all a y'all are acts." Brother Ali metaphorically describes his passion and commitment to hip-hop as "bleeding on the track." While other acts may be concerned with creating an image and style that appeals to the masses, Brother Ali and the Rhymesayers label advocate for quality tracks with sociopolitical lyrics, which include critiques of white privilege, political agendas of Presidential candidates, and capitalism. The Rhymesayers collective distance themselves from the majors by creating an alternative culture embodied by the moniker: "for the love of hip-hop."

Indies also claim that they make music regardless of their financial success. They exhibit lyrics that demonstrate their passion and drive for creating hip-hop music despite long, arduous roads to commercial success (Avalon 2011). They cite limited economic and cultural support in comparison with major acts, which hinder their ability to garner economic success and cultural notoriety in the music industry. Despite this, they develop an alternative culture under the premise that they make hip-hop music as a means of making a living regardless of financial success and fame.

For instance, rap duo People Under the Stairs have written of their struggles to obtain financial stability and success through rapping. People Under the Stairs, consisting of members Thes One and Double K, have bounced around different indie companies until being signed to $\mathrm{Om}$ Records in 1999 to a four-album deal, and later to other small labels such as Basement Records, Gold Dust Media, and Thes One's own label PieceLock 70. In their track "Keepin' It Live" (2002b), they spit: "what you mean I ain't making no money off this hip-hop shit?" As seen by their movement through various labels, People Under the Stairs have maintained a strong desire to pursue their musical interests despite initially facing low profit margins. Underlying their music is the claim that they can achieve success through alternative avenues rather than adopting the culture and ideologies of the majors. 
Similarly, Swollen Members has obtained mainstream success despite being labeled an alternative rap group. Under smaller companies Battle Axe and Suburban Noize, they have released nine studio albums as of 2014. Members Madchild and Prevail initially created their own label, Battle Axe Records, to release their debut album Balance and was met with critical acclaim, moderate record sales, and an eventual appearance on NBA Live's 2002 soundtrack. On "Long Way Down" (2002), a track on Monsters in the Closet, they reiterate that choosing to do hiphop music requires that you love the music. They write from their own experiences when they created their own label to release their own brand of music, which required releasing four albums under a limited budget before being signed to a larger independent company entitled Suburban Noize. Their new indie label was founded under the idea that alternative suburban rap culture could be developed without the external pressures of large corporations.

Macklemore and Ryan Lewis are the most visible case of mainstream success by an independent rap duo (Greenburg 2013b). In 2012, they released the album entitled The Heist and achieved platinum status. In the song "Make the Money" (2012b), Macklemore writes: "if I'd done it for the money, I'd have been a fucking lawyer." The song focuses on their desire to change the hip-hop game rather than purely giving into the money and fame. On the chorus, they write that they have remained faithful to the indie circuit and stayed true to their intentions as artists despite the possibility of going broke (Smith 2012). They both understand the limited opportunities in hip-hop as only a few achieve financial success. Artists who have remained independent throughout their careers have reinforced the cultural moniker that they do hip-hop for the love of the music and in turn argue that financial and material success are secondary.

\section{"Keeping It Real"}

A second emergent theme is one of "keeping it real," or staying true to hip-hop and its roots, which can be traced back to the South Bronx in the 1970s. Hip-hop's origins have been represented in its pillars consisting of rapping, DJing, breakdancing, and graffiti. Its content was also focused primarily on the economic hardships of low-income minority communities in New York, which included problems of rampant gentrification, social hardships such as racial discrimination against 
African-Americans and Latinos, and the prison industrial complex. In response to these hardships, hip-hop offered a wide array of social representation ranging from the creation of enclaves dedicated to hip-hop's subculture to social critiques aligned with the Civil Rights Movement, the Black Panthers, and the Young Lords (Alridge 2005; Au 2005; Chang 2005; Forman 2000; Morgan and Bennett 2011; Pough 2004; Stapleton 1998). Independent musicians of this genre have made the claim that the culture has moved away from these origins due to commodification and cooptation (Pough 2004; Rose 2008). This has led to a revival of keeping it real (Hodgman 2013) wherein artists stay true to the original message and essence of hip-hop culture and maintain a high quality product concordant with hip-hop's concept of authenticity.

Indies have expressed a desire to maintain the original message and essence of hip-hop culture. Concordant with their previous arguments of "doing it for the love," Rhymesayers' signees such as Aesop Rock and Atmosphere directly reference old school hip-hop community members who embody what the culture is supposed to be for them. Atmosphere writes in "Blamegame" (2002c) to "put your hand up if you remember the Juice Crew, they don't make em' like they used to." The Juice Crew was a collective in the 1980s founded by Marley Marl and Mr. Magic and included future stars such as Big Daddy Kane and Biz Markie. Atmosphere references the Juice Crew's ingenuity in the early hip-hop era before being dismantled by privatization and corporatization. Aesop Rock spits in "Coma" (2001b): "he was maverick enough but still scraped up, Taki 183 innovation for the kids." These lyrics reference graffiti artist Taki 183. In New York, his simple tag, "Taki 183," spawned many imitators who began mimicking his style throughout the boroughs. Tagging spread so quickly that it even received widespread media attention from the New York Times in 1971 (Kennedy 2011). Both Aesop Rock and Atmosphere reference the roots of hip-hop to emphasize the importance of maintaining its message of resistance to white mainstream culture. Yet Hodgman (2013) points out that white performers generally downplay the importance of race in their music and instead highlight class-based values and remaining "true to the game" in their construction of authenticity.

Underlying Atmosphere's argument of a respect for the game is the utilization of the term authentic. Brother Ali, a fellow member of the Rhymesayers label, writes on "Crown Jewel" (2009b) that "there's a 
certain type of glow that emanates, off the authentic that a fake could never imitate." Binary Star, a rap duo composed of One Be Lo and Senim Silla on Subterraneous Records, similarly writes on "Fellowship" (2000f) that ultimately "if you're hungry for some real hip hop, we came to feed you." For these artists, authenticity resembles the claim that they produce real hip-hop for their fans concordant with the urban, working-class landscapes of its origins (Ogbar 2007: 39). Asante (2008) reiterates these sentiments by claiming that authentic acts portray African-Americans and other disenfranchised racial groups as diverse social actors capable of innovation and culture, rather than monoliths of violence and misogyny.

Finally, the concept of authenticity is maintained by putting out a quality product that engages in an honest and open dialogue with listeners about their thoughts and life experiences to demonstrate that hiphop has not been censored and diluted by mainstream artists and major record labels (Asante 2008). Rap duo Binary Star writes in "Reality Check" (2000g) to "never sell (his) soul is (his) philosophy" and that "honestly, (his) number one policy is quality." Rapsody, a female rapper signed under 9th Wonder's It's A Wonderful World Music Group (IWWMG), similarly raps in "Believe Me" (2012c) that IWWMG puts out quality music despite making significantly less money than major acts. She cites 9th Wonder's achieved critical acclaim for quality music production and frequent music collaborations with successful hip-hop acts (BET 2015).

The term authenticity represents a claim that artists have kept the culture alive by keeping it real despite the corporatization of the business. Previous literature (Rose 2008) questions if hip-hop has died due to over-saturation in the market by mainstream companies and acts. As Rhymesayer's Aesop Rock argues in "Save Yourself" (2001c): "promise me you gon' (...) recognize, what you holdin ain't really broken?” Blue Scholars adds in "Southside Survival" (2005) that contrary to the popular saying that hip-hop is dead, they argue that it is not broken but that it continues to thrive. It has just moved to the indie scene where many acts believe they have remained true to its history, paid respects to its origins, and maintained a high level of quality similar to its predecessors. Ultimately, conceptions of authenticity in indie hip-hop are socially constructed by artists (and fans) though signifiers (McLeod 1999) such as doing it for the love of the music and keeping it real (Hodgman 2013). 


\section{CONCLUSION}

This chapter explicates the cultural claims independent hip-hop artists in the post-golden era make regarding class relations within the music industry and within broader class relations in the USA. First, indie musicians' lyrics present messages of resistance against the majors. In particular, they criticize: (1) mainstream artists, (2) large radio stations, and (3) major record labels. Second, their messages reject large corporations in mainstream culture in favor of smaller companies and niche subcultures. Finally, results indicate that indie culture is often predicated upon alternative cultural ideals of music production such as doing it for the love of the music and honoring hip-hop's origins. My findings uncover messages of a distinct subculture predicated upon the rejection of mainstream society and the formation of an underground movement.

\section{REFERENCES}

Aesop Rock. 2001a. "Labor.” Labor Days. Definitive Jux.

Aesop Rock. 2001b. "Coma." Labor Days. Definitive Jux.

Aesop Rock. 2001c. "Save Yourself." Labor Days. Definitive Jux.

Akom, Antwi. 2009. "Critical Hip Hop Pedagogy as a Form of Liberatory Praxis." Equity \& Excellence in Education 42 (1): 52-66.

Alridge, Derrick. 2005. "From Civil Rights to Hip Hop: Toward a Nexus of Ideas." The Journal of African American History 90 (3): 226-252.

Asante, Molefi Kete. 2008. It's Bigger Than Hip Hop: The Rise of the Post-HipHop Generation. New York: St. Martin's Press.

Atmosphere. 2002a. "One of a Kind." God Loves Ugly. Rhymesayers/Fat Beats. Atmosphere. 2002b. "Give Me." God Loves Ugly. Rhymesayers/Fat Beats. Atmosphere. 2002c. "Blamegame." God Loves Ugly. Rhymesayers/Fat Beats. Au, Wayne. 2005. "Fresh Out of School: Rap Music's Discursive Battle with Education." The Journal of Negro Education 74 (3): 210-220.

Avalon, Moses. 2011. "What Are the Vegas Odds of Success on Today's Major Label Record Deals?" Retrieved April 15, 2016. www.mosesavalon.com/ what-are-the-vegas-odds-of-success-on-todays-major-label-record-deal/.

Ball, Jared. 2009. "FreeMix Radio: The Original Mixtape Radio Show: A Case Study in Mixtape 'Radio' and Emancipatory Journalism." Journal of Black Studies 39 (4): 614-634.

Berger, David, and Richard Peterson. 1975. "Cycles in Symbol Production: The Case of Popular Music." American Sociological Review 40: 158-173.

BET. 2015. "10 Things You Should Know About Rapsody." Retrieved April 15, 2016. http://www.bet.com/music/photos/2015/03/10-things-youshould-know-about-rapsody.html. 
Binary Star. 2000a. "Masters of the Universe." Masters of the Universe. Subterraneous Records.

Binary Star. 2000b. "Honest Expression." Masters of the Universe. Subterraneous Records.

Binary Star. 2000c. "Binary Shuffle." Masters of the Universe. Subterraneous Records.

Binary Star. 2000d. "Indy 500." Masters of the Universe. Subterraneous Records.

Binary Star. 2000e. "Conquistadors." Masters of the Universe. Subterraneous Records.

Binary Star. 2000f. "Fellowship." Masters of the Universe. Subterraneous Records.

Binary Star. 2000g. "Reality Check." Masters of the Universe. Subterraneous Records.

Blackalicious. 2002. "Purest Love." Blazing Arrow. MCA Records.

Blu and Exile. 2007a. "Simply Amazin'." Below the Heavens. Sound in Color.

Blu and Exile. 2007b. "Soul Amazing." Below the Heavens. Sound in Color.

Blu and Exile. 2007c. "The Narrow Path." Below the Heavens. Sound in Color.

Blue Scholars. 2005. "Southside Survival." The Long March. Massline.

Brother Ali. 2009a. "The Preacher." Us. Rhymesayers Group.

Brother Ali. 2009b. "Crown Jewel." Us. Rhymesayers Group.

Bush, John. 2003. "Hieroglyphics: Full Circle AllMusic Review." Retrieved April 15, 2016. www.allmusic.com/album/full-circle-mw0000326859/ awards.

Chang, Jeff. 2005. Can't Stop Won't Stop: A History of Hip-Hop Generation. New York: St. Martin's Press.

Dimitriadis, Greg. 2009. Performing Identity/Performing Culture: Hip Hop as Text, Pedagogy, and Lived Practice. New York: Peter Lang.

Drake, David. 2015. "If It Ain't About the Money: Does Hip-Hop Still Need Major Labels?" Retrieved April 15, 2016. www.complex.com/ music/2015/01/hip-hop-major-labels-2015.

Ducker, Eric. 2014. "A Rational Conversation: The 20-Year-Old Album That's MF Doom's Missing Link.” Retrieved April 15, 2016. www.npr.org/sections/therecord/2014/11/06/361216399/a-rational-conversation-the-20year-old-album-thats-mf-dooms-missing-link.

Dyson, Michael Eric. 2010. Know What I Mean: Reflections on Hip-Hop. New York: Basic Civitas.

Ferris, Kerry. 2007. "The Sociology of Celebrity." Sociological Compass 1 (1): 371-384.

Forman, Murray. 2000. "Represent: Race, Place, and Space in Rap Music." Popular Music 19 (1): 65-90.

Greenburg, Zach O' Malley. 2013a. “Tech N9ne: Hip-Hop's Secret Mogul.” Retrieved April 15, 2016. www.forbes.com/sites/zackomalleygreenburg/ 2013/09/24/tech-n9ne-hip-hops-secret-mogul/. 
Greenburg, Zach O' Malley. 2013b. “Macklemore: The Biggest GrammyNominated, Platinum-Selling Paradox in Music.” Retrieved April 15, 2016. http://www.forbes.com/sites/zackomalleygreenburg/2013/12/16/macklemore-the-biggest-grammy-nominated-platinum-selling-paradox-in-music/\#32b7305aabe4.

Hard Knock TV. 2013. "Immortal Technique and Tech N9ne Talk Independent Movement, Technology, Black + Brown.” Retrieved April 15, 2016. www. youtube.com/watch?v=xzR4yDUUgO8.

Harkness, Geoff. 2012. "True School: Situational Authenticity in Chicago's HipHop Underground." Cultural Sociology 6 (3): 283-298.

Harrison, Anthony Kwame. 2006. "Cheaper Than a CD, Plus We Really Mean It: Bay Area Underground Hip Hop Tapes as Subcultural Artefacts." Popular Music 25: 283-301.

Hesmondhalgh, David. 1999. "Indie: The Institutional Politics and Aesthetics of a Popular Music Genre." Cultural Studies 13 (1): 34-61.

Hess, Mickey. 2005. "Metal Faces, Rap Masks: Identity and Resistance in HipHop's Persona Artist.” Popular Music and Society 28 (3): 297-311.

Hibbett, Ryan. 2005. "What Is Indie Rock?" Popular Music and Society 28 (1): 55-77.

Hieroglyphics. 2003a. "Let It Roll." Full Circle. Hieroglyphics Imperium Recordings.

Hieroglyphics. 2003b. "Prelude." Full Circle. Hieroglyphics Imperium Recordings.

Hieroglyphics. 2003c. "Powers That Be." Full Circle. Hieroglyphics Imperium Recordings.

Hill, Marc Lamont. 2009. Beats, Rhymes, and Classroom Life: Hip-Hop Pedagogy and the Politics of Identity. New York: Teachers College Press.

Hodgman, Matthew. 2013. "Class, Race, Credibility, and Authenticity Within the Hip-Hop Music Genre." Journal of Sociological Research 4 (2): 402-413.

Immortal Technique. 2003a. "One Remix." Revolutionary Vol. 2. Viper Records.

Immortal Technique. 2003b. "Industrial Revolution." Revolutionary Vol. 2. Viper Records.

Immortal Technique. 2003c. "The Message and the Money." Revolutionary Vol. 2. Viper Records.

Immortal Technique. 2003d. "Freedom of Speech." Revolutionary Vol. 2. Viper Records.

Johnson, Christopher. 2008. “Danceable Capitalism: Hip-Hop's Link to Corporate Space." The Journal of Pan African Studies 2 (4): 80-92.

Jones, Steve. 2002. "Music That Moves: Popular Music, Distribution and Network Technologies." Cultural Studies 16 (2): 213-232.

Kennedy, Randy. 2011. "Celebrating Forefather of Graffiti." Retrieved April 15, 2016. www.nytimes.com/2011/07/23/arts/design/early-graffiti-artist-taki183-still-lives.html?_r=0. 
KRS-ONE. 2007. “Nothing New.” Hip-Hop Lives. Koch Records.

Leard, Diane, and Brett Lashua. 2006. "Popular Media, Critical Pedagogy, and Inner City Youth." Canadian Journal of Education 29 (1): 244-264.

Lindvall, Helienne. 2010. "Behind the Music: When Artists Are Held Hostage by Labels." Retrieved January 1, 2018. https://www.theguardian.com/ music/musicblog/2010/apr/15/artists-held-hostage-labels.

Macklemore and Ryan Lewis. 2012a. "Jimmy Iovine." The Heist. Macklemore LLC-ADA.

Macklemore and Ryan Lewis. 2012b. "Make the Money." The Heist. Macklemore LLC-ADA.

Maher, George Ciccariello. 2005. "Brechtian Hip-Hop: Didactics and SelfProduction in Post-Gangsta Political Mixtapes." Journal of Black Studies 26 (1): 129-160.

Maher, George Ciccariello. 2007. “A Critique of DuBoisian Reason: Kanye West and the Fruitfulness of Double Consciousness." Journal of Black Studies 39 (3): 371-401.

McLeod, Kembrew. 1999. "Authenticity Within Hip-Hop and Other Cultures Threatened with Assimilation." Journal of Communication 49 (4): $134-150$.

MF DOOM. 2009. “Gazillion Ear.” Born Like This. Lex.

Michaels, Sean. 2010. “Outkast's Record Label Blocks Big Boi and Andre 3000 Collaboration.” Retrieved January 1, 2018. https://www.theguardian.com/ music/2010/jun/09/outkast-big-boi-andre-3000.

Mills, Brad. 2000. "Binary Star: Masters of the Universe, AllMusic Review." Retrieved April 15, 2016. www.allmusic.com/album/ masters-of-the-universe-mw0000106803.

Moore, Ryan. 2007. "Friends Don't Let Friends Listen to Corporate Rock: Punk as a Field of Production." Journal of Contemporary Ethnography 36 (4): $438-474$.

Morgan, Marcyliena, and Dionne Bennett. 2011. "Hip-Hop \& the Global Imprint of a Black Cultural Form." Dedalus: The Journal of the American Academy of Arts \& Sciences 140 (2): 176-196.

Myer, Letrez, and Christine Kleck. 2007. "From Independent to Corporate: A Political Economic Analysis of Rap Billboard Toppers." Popular Music and Society 30 (2): 137-148.

The NE Hip-Hop. 2013. "Immortal Technique on Being Independent." Retrieved April 15, 2016. www.youtube.com/watch?v=gRrlBwOBRJA.

Newman, Michael. 2005. "Rap as Literacy: A Genre Analysis of Hip-Hop Cyphers." Text 25 (3): 399-436.

Ogbar, Jeffrey. 2007. Hip-Hop Revolution: The Culture and Politics of Rap. Lawrence: University Press of Kansas. 
Ostrow, Jonathan. 2010. “Indie vs. Major: Which Record Label Contract Is Right for You?" Retrieved April 15, 2016. www.musicthinktank.com/mttopen/indie-vs-major-which-record-label-contract-is-right-for-you.hml.

People Under the Stairs. 2002a. "Acid Raindrops.” OST. Om Records.

People Under the Stairs. 2002b. “Keepin’ It Live.” OST. Om Records.

Perry, Imani. 2004. Prophets of the Hood: Politics and Poetics in Hip Hop. Durham, NC: Duke University Press.

Platon, Adelle. 2017. "Chance the Rapper Talks Fatherhood, Dealing with Anxiety, Record Labels \& Possibly Selling His Next Album." Retrieved January 1, 2018. https://www.billboard.com/biz/articles/7720954/ chance-the-rapper-talks-fatherhood-dealing-with-anxiety-record-labels-possibly.

Potter, Russell. 1995. Spectacular Vernaculars: Hip-Hop and the Politics of Postmodernism. Albany: State University of New York Press.

Pough, Gwendolyn. 2004. Check It While I Wreck It: Black Womanhood, Hip-Hop Culture, and the Public Sphere. New Hampshire: Northeastern University Press.

Rapsody. 2012a. "Kind of Love." The Idea of Beautiful. Jamla.

Rapsody. 2012b. "The Cards." The Idea of Beautiful. Jamla.

Rapsody. 2012c. "Believe Me." The Idea of Beautiful. Jamla.

Rose, Tricia. 2008. The Hip Hop Wars: What We Talk About When We Talk About Hip Hop-And Why It Matters. New York: Basic Civitas.

Smith, Clyde. 2012. "The Heist: Macklemore \& Ryan Lewis Take DIY Route to iTunes \#1." Retrieved April 15, 2016. http://www.hypebot.com/hypebot $/ 2012 / 10 /$ the-heist-macklemore-ryan-lewis-take-diy-route-to-itunes- 1 . html.

Stapleton, Katina. 1998. "From the Margins to Mainstream: The Political Power of Hip-Hop." Media, Culture \&́ Society 20: 219-234.

Steiner, B. J. 2014. "Rap Albums That Got Shelved into Oblivion." Retrieved January 1, 2018. http://www.complex.com/music/2014/11/ rap-albums-that-never-came-out/.

Swollen Members. 2002. "Long Way Down." Monsters in the Closet. Battle Axe.

Taylor, Carl, and Virgil Taylor. 2007. "Hip-Hop Is Now: An Evolving Youth Culture." Reclaiming Children and Youth 15 (4): 210-213.

Tech N9ne. 2008a. "Like Yeah." Killer. Strange Music.

Tucker, Nichole. 2015. "Tech N9ne Tells the Breakfast Club He 'Will Never Go Mainstream.' Here's Why." Retrieved April 15, 2016. www.inquisitr. com/1991886/tech-n9ne-says-real-music-is-supposed-to-spread-and-shinebut-he-will-never-go-mainsream-heres-why/.

Vito, Christopher. 2015. "Who Said Hip-Hop Was Dead?: The Politics of HipHop Culture in Immortal Technique's Lyrics." International Journal of Cultural Studies 18 (4): 395-411.

Watkins, S. Craig. 2005. Hip Hop Matters: Politics, Pop Culture, and the Struggle for the Soul of a Movement. Boston, MA: Beacon Press. 
Wells-Wilbon, Rhonda, Nigel Jackson, and Jerome Schiele. 2010. "Lessons from the Maafa: Rethinking the Legacy of Slain Hip-Hop Icon Tupac Amaru Shakur." Journal of Black Studies 40 (4): 504-526.

Zafar, Aylin. 2013. "What It's Like When a Label Won't Release Your Album." Retrieved January 1, 2018. https://www.buzzfeed.com/azafar/what-happens-when-your-favorite-artist-is-legally-unable-to?utm_term=.ux0Ew82pe\#. guldxWo63.

Open Access This chapter is distributed under the terms of the Creative Commons Attribution 4.0 International License (http://creativecommons.org/ licenses/by/4.0/), which permits use, duplication, adaptation, distribution and reproduction in any medium or format, as long as you give appropriate credit to the original author(s) and the source, a link is provided to the Creative Commons license and any changes made are indicated.The images or other third party material in this chapter are included in the work's Creative Commons license, unless indicated otherwise in the credit line; if such material is not included in the work's Creative Commons license and the respective action is not permitted by statutory regulation, users will need to obtain permission from the license holder to duplicate, adapt or reproduce the material.

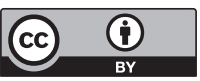

